\title{
Continuous Negotiation in Climate Adaptation: The Challenge of Co-Evolution for the Capability Approach to Justice
}

\author{
Lieke Brackel $\mathbb{1}$ \\ Department of Values, Technology and Innovation, Faculty of Technology, Policy and Management, \\ Delft University of Technology, 2628 BX Delft, The Netherlands; a.k.c.brackel@tudelft.nl
}

check for

updates

Citation: Brackel, L. Continuous Negotiation in Climate Adaptation The Challenge of Co-Evolution for the Capability Approach to Justice. Sustainability 2021, 13, 13072. https://doi.org/10.3390/su132313072

Academic Editor: Oz Sahin

Received: 30 September 2021 Accepted: 17 November 2021 Published: 25 November 2021

Publisher's Note: MDPI stays neutral with regard to jurisdictional claims in published maps and institutional affiliations.

Copyright: (C) 2021 by the author. Licensee MDPI, Basel, Switzerland. This article is an open access article distributed under the terms and conditions of the Creative Commons Attribution (CC BY) license (https:// creativecommons.org/licenses/by/ $4.0 /)$.

\begin{abstract}
The capability approach is increasingly presented as a promising approach to address questions of justice in local climate adaptation. In an attempt to integrate environmental protections into the capability approach, Breena Holland developed the meta-capability Sustainable Ecological Capacity to establish substantive ecological limits. This article, however, empirically demonstrates that defining ecosystem thresholds in co-evolving systems is subject to conflict and continuous negotiation. Taking the Haringvliet dam in the Dutch South-West Delta as an illustrative case, this paper shows how people uphold different views about the Haringvliet's most desirable ecosystem state. Future shifts in the socio-ecological system, such as decreased fresh water availability and sea-level rise, are expected to uproot today's compromise about chloride levels in the Haringvliet. This suggests that anticipatory water management should not only address climate impacts, but also prepare for re-negotiations of established ecological thresholds. The associated politics of climate adaptation deals with questions about which functions to protect, at what costs and for whom. Hence, it is critical to integrate procedural justice and attention to political inequalities in capabilities-based adaptation justice frameworks.
\end{abstract}

Keywords: justice; capability approach; climate adaptation; co-evolution; socio-ecological systems; political ecology; ethics

\section{Introduction}

If the world fails to take sufficient climate action, large parts of the Earth can become uninhabitable [1]. Climate impacts vary over different geographic locations, and vulnerability to climate risks such as floods, droughts and heat waves intersects with all kinds of existing inequalities [2-4]. Climate adaptation is defined by the Intergovernmental Panel on Climate Change (IPCC) as 'the process of adjustment to actual or expected climate and its effects, in order to moderate harm or exploit beneficial opportunities' [5]. Assuming that protection is technically and economically feasible, political choices have to be made about what kind of landscapes and life forms to sustain in the future. For instance, when the sea level rises, a coastal society can choose to either protect land against flooding or alternatively engage in forms of managed retreat [6,7]. Although the pace of climate change is unprecedented, large-scale land use transitions are not new. For example, many delta systems have been modified by engineering interventions to accommodate growing human settlements. Lessons from past controversies about human-induced ecosystem state shifts can help to prepare for the local impacts of human-induced climate change.

The capability approach is promising to address questions of justice in climate adaptation, because it is open-ended, pluralistic, and sensitive to contextual differences [8-12]. Translating the capability approach to environmental policy, Breena Holland argues that substantive ecological limits should be included. According to her, prioritizing the protection of 'Sustainable Ecological Capacity' as a meta-capability is necessary since healthy ecosystems are preconditions for all other human capabilities [13-16]. This instrumental line of argumentation helps to justify ecological protection and climate action. However, if 
policymakers want to specify ecological limits to address local controversies, they will run into problems.

The objective of this article is to show that establishing a priori ecological limits is insufficient to address controversies in co-evolving ecosystems. Drawing from empirical insights about ecosystem state politics, the article proposes a way to further develop capabilities-based frameworks for adaptation justice [17]. The in-depth case study analyzed is the opening of the Haringvliet dam in the Dutch South-West Delta. The reason for using this case is that the controversy clearly illustrates difficulties with establishing static thresholds in co-evolving systems. The construction of the Haringvliet dam transformed the dynamic brackish estuary into a stagnant fresh-water lake. The paper describes the subsequent decades-long debate about an acceptable and desirable threshold for salt-water intrusion, which resulted in a peculiar compromise: the partial opening of the dam under strict conditions.

Previous and current struggles about shifts in socio-ecological system states, such as the Haringvliet controversy, provide an angle to better understand and anticipate future adaptation conflicts. Comparable controversies can revolve around changing the water table, re-distributing river flows, or setting new water quality and biodiversity targets. Due to the importance of context and situated knowledge, this article focuses on NorthWestern Europe and The Netherlands in particular. Nevertheless, future research may build upon theoretical insights that have a wider explanatory value. Connecting insights from empirical research and Science and Technology Studies to the field of philosophy helps to empirically inform and further develop approaches in climate adaptation ethics.

The outline of this paper is as follows. In Section 2, key concepts used in the analysis are explained and embedded in the scientific literature. Section 3 describes the Haringvliet controversy and Section 4 discusses the implications of the studied controversy for the capability approach. In sum, the paper explains how understanding the Dutch South-West Delta as a co-evolving socio-ecological system challenges the notion of ecological limits in the capability approach. Additional pre-conditions for political equality are discussed to improve the relevance of the capability approach to local climate adaptation politics [18-20].

\section{Background: Co-Evolving Socio-Ecological Systems and the Capability Approach}

In this paper, climate adaptation is understood as a continuous process of negotiation that takes place in co-evolving socio-ecological systems. This section explains the details of this statement and positions the corresponding concepts in the literature (socioecological systems, co-evolution, adaptation politics, capabilities, and the meta-capability of Sustainable Ecological Capacity).

\subsection{Socio-Ecological Systems}

Climate adaptation takes place in existing socio-ecological systems (SES). These systems have already experienced quite some shifts and 'processes of adjustment' over time, either man-made or due to geomorphic processes. The concept of the socio-ecological system has an origin in ecology [21,22], but other academic perspectives have joined, including ecological economics [23], human geography [24,25], sociology and political science [4,5,26-29]. Adjacent concepts are co-production [27], socio-hydrology [28], hydrosocial analysis [29], and hydro-social territories [30]. All point to the inherent entanglement of humans and nature [31]. Acknowledging the mutual constitution of human, social and technical systems helps to understand system dynamics and avoid oversimplifications. In this paper, we use the term socio-ecological system to describe the messy co-constitutive development process of the Dutch Delta [32-36].

\subsection{Co-Evolution}

The notion of co-evolution is used to describe the development of socio-ecological systems over time. Co-evolutionary perspectives highlight that climate adaptation is part of wider system dynamics (including the policy makers intervening and the researchers 
studying these systems). The ecological economist Richard Norgaard argues that natural and social systems co-evolve $[23,36,37]$. In a process of co-evolution, different elements of a system are not only intertwined, but also respond to each other. As a consequence, not only the entities themselves but also the relations between elements are constantly changing [36] (p. 24). For example, in the Dutch Delta, co-evolution is illustrated by changes over time in the water management regime. After World War II, the popular view among practitioners and scientists was that 'efficient' land management requires large and straight plots and mechanization. Large-scale land consolidation followed, and meandering creeks disappeared. As an unintended consequence, the system's water storage capacity decreased and became more vulnerable to droughts. Due to climate change, heat waves and droughts start to occur more frequently. Subsequently, citizens, policymakers and scientists rediscovered the value and lost functionality of these creeks. At that point, however, the Delta system had already changed significantly in shape. Changes in terms of cropping patterns, infrastructure development and investments contributed to new path-dependencies and technological lock-ins. Hydraulic infrastructures such as drainage systems and dams are part of the co-evolving delta system [38]. History and path-dependency are important: delta systems are not only dynamic within one system state, but also shift to different socio-ecological system states over the course of time.

Co-evolutionary perspectives acknowledge the dynamism and slow processes of change that are inherently part of delta systems. This reflects the absurdity of trying to freeze or preserve a static imaginary of an ecosystem that never was static to begin with. For instance, European Union Directives such as the Water Framework Directive and the Habitat Directive contain static policy goals that do no justice to the complexity of hydromorphodynamic processes [39]. Dryzek and Pickering draw the normative conclusion in The Politics of the Anthropocene that 'co-evolution may often be a more appropriate way of thinking than nature restoration or conservation' [17] (p. 30). A co-evolutionary analysis can address the anthropocentric bias in public decision-making by drawing attention to the role of non-human and geomorphological forces [26] (p. 882). The active role of 'nature' needs to be recognized in socio-ecological systems research [17] (p. 10). Studying co-evolution means paying attention to the random and unexpected elements that can enter a complex and dynamic system at any time [17] (p. 24).

A critique of the co-evolutionary perspective is that concepts stemming from biology such as such as 'adaptation', 'resilience', 'evolution' and 'vulnerability' are multiinterpretable and can have a depoliticizing effect [40]. There is a risk that ecological concepts mask political choices about how to engage with humans and non-humans in ecosystem management [24,41-47], while politics form an integral part of how socioecological systems develop and function [24,47-49].

\subsection{Adaptation Politics}

Due to climate change, existing policies and agreements about environmental thresholds may have to be re-negotiated. The IPCC definition of climate adaptation reflects the normative nature of climate adaptation and resilience policies [47,49]. Multiple positions are possible about what we find 'beneficial opportunities' and acceptable means to 'moderate harms'. This is relevant at the global level, since we are all dependent upon healthy atmospheric conditions, but also at the local level. For instance, the shape of coastal zones in the future depends upon the influence of sea-level rise, as well as on coastal societies that can choose between different management options [50-52]. According to Eriksen et al., adaptation is 'a socio-political process that mediates how individuals and collectives deal with multiple and concurrent environmental and social changes' [42] (p. 524). It is a political process, because there is disagreement about what to prioritize in public policy and what kind of life to protect. Furthermore, the notion of 'transformative adaptation' is frequently used in adaptation research to distinguish adaptation responses that tackle the root causes of human vulnerability (often linked to socio-economic inequalities) from adaptation responses that strengthen current inequalities or sustain the status quo $[42,44,52]$. 
Besides, there is not one final decision to be made about what kind of climate adaptation measures people prefer. Due to ongoing social and environmental changes, climate adaptation can be conceived of as continuous negotiation in co-evolving systems.

\subsection{The Capability Approach}

The capability approach is frequently mentioned as a fruitful approach to address questions of justice in climate adaptation $[8,11,12,14,17,53-58]$. Amartya Sen developed the concept of capabilities to critique the informational and normative bases of other approaches to justice in the liberal tradition, namely, utilitarianism (cost-benefit analysis), libertarianism, Rawlsian justice (primary goods) and aggregative neo-liberal economics ([20] (p. 459), [59,60]). According to Sen, we should look at what people are actually able to do with the resources they have available, not at the distribution of these resources. The capability approach can help to improve consequentialist assessment of public policy and social outcomes [58]. The alternative evaluative space created by the capability approach is favorable because of its ability to incorporate contextual factors and differences between individuals. Capabilities need to be specified at the local level. This open-ended feature enables flexibility and room for democratic determination of valuable capabilities. Which capabilities to protect for the future is a key question for adaptation politics.

\subsubsection{Capabilities and Functionings}

Capabilities 'are what people are able to do and be, and functionings are the corresponding [realized] achievements' [60] (p. 38). The distinction between functionings and capabilities made by Sen helps to discuss what kind of real opportunities, also conceived of as freedoms, humans have access to. The capability approach can show differences between the needs of individuals in climate adaptation and justify additional government support $[60,61]$. Studying the context involves investigating so-called social and environmental conversion factors that influence whether people are able to transform capabilities into functionings.

Existing inequalities in a society can lead to 'corrosive' vulnerabilities when people are also faced with climatic stressors [61]. For example, people who already struggling with low income or high debts have fewer financial reserves to rely on during a crisis, let alone have the funds to anticipatorily invest in alternative livelihood options. The inclusion of contextual considerations makes the capability approach information intensive. Nevertheless, it allows for capabilities-based adaptation frameworks to account for social class, race or gender differences. This avoids simplifications, such as addressing diverse farmers as one monolithic group.

\subsubsection{Selecting Capabilities}

It should be noted that the concept of capability itself is value-neutral [60]. A multitude of interpretations and versions of 'the capability approach' exist in combination with different normative frameworks for how to select and prioritize capabilities. Not all people agree on what the most valuable or important capabilities are. This is especially relevant if these capabilities can only be realized through collective (government) action. Additional choices and/or frameworks are required to identify which capabilities a government should guarantee and decide upon trade-offs between capabilities [60,62]. Amartya Sen and Martha Nussbaum, the two developers of the capability approach, already have different ideas about how to arrive at a selection of basic capabilities.

Where Amartya Sen leaves the selection more open and relies on deliberation (public reason), Nussbaum has established a non-procedural list of basic capabilities. In the capabilities literature, scholars following Sen rely on procedural justice and deliberative methods to select basic capabilities at the local level $[20,60,63,64]$. For Amartya Sen, freedom is the primary concerns and he leaves the selection of capabilities to the people involved [59,65]. The importance of including the people involved is also stressed by Schlosberg, who argues that recognition of different ways of being in the world is a key demand from environ- 
mental justice groups [18]. The open-ended capability approach can accommodate this diversity. However, Sen's reliance on procedural justice is criticized for providing too little substantive protections of justice.

Martha Nussbaum, on the contrary, relies on independent moral argument and developed a list of ten basic capabilities that require a-priori guarantees. Nussbaum's list of basic capabilities contains: (1). life, (2) bodily health, (3) bodily integrity, (4) senses, imagination and thought, (5) emotions, (6) practical reason (7) affiliation, (8) other species, (9) play, (10) control over ones' environment [66]. The list was developed in close collaboration with people from all over the world $[13,66]$. The list is intentionally vague and open-ended to be able to attend to cultural differences and allow for local specification. Still, Nussbaum's list is criticized for lacking (democratic) legitimacy and being based on Western liberal-centric assumptions [20]. Building upon Nussbaum's list, Breena Holland developed the metacapability of Sustainable Ecological Capacity to incorporate environmental protection in the capability approach [13].

\subsubsection{The Meta-Capability Sustainable Ecological Capacity}

The capability approach receives criticism for its anthropocentric foundation. The focus is on human flourishing and the environment is only discussed as part of the context that influences the translation process of human capabilities to functionings (i.e., as conversion factors) [60] (p. 189). To solve this problem, Schlosberg and Dryzek and Pickering extend the capability approach by also granting capabilities to communities, species and ecosystems [8,17]. Yet, Robeyns objects to these extensions of the capability approach that they are not aligned with its theoretical foundations that are at the core about human agency and functioning [60]. A counter-objection to using anthropocentric interpretations of the capability approach, however, would be that they do no justice to the intrinsic value of ecosystems, nor to the increased awareness of the mutual entanglement between humans and nature. Drawing from earlier insights about co-evolution, the environment and non-human actors are not to be understood as static décor pieces to human justice affairs [17]. Research into ecocentric (capabilities) approaches to justice are important and developing [67-69]. For the purpose of this paper, however, it is sufficient to build upon the anthropocentric and instrumental argumentations, such as those developed by Holland [13].

Nature protection can also be defended by pointing to the indispensable importance of ecosystem functioning for human flourishing. Holland aims to integrate substantive a priori protections of ecosystem functioning in the capability approach: the meta-capability of Sustainable Ecological Capacity. The environment's ecological functioning is a meta-capability because it is a precondition of all the basic capabilities on Nussbaum's list $[13,15,16]$. According to Robeyns, the conceptualization of 'meta-capability' is off because the environment and ecosystem services are not capabilities themselves (real opportunities for human beings). Alternatively, the environment should have been conceptualized as a non-substitutable absolutely necessary pre-condition for human well-being in terms of capabilities [60] (p. 171). Nevertheless, whether conceived of as a 'meta-capability' or as a 'non-substitutable pre-condition', the point remains the same that (non-negotiable) ecological limits can be added to the capability approach. The strength of this line of reasoning is that it foregrounds the existential dependence of human agency and functioning on their environment.

In the following sections of this paper, conflicts about socio-ecological system state shifts are analyzed using the idea of ecological limits from Holland's anthropocentric non-procedural version of the capability approach. In Allocating The Earth, she argues for identifying ecological limits and capability ceilings [14]. The collapse of ecosystems ultimately endangers all basic human capabilities. For instance, the capability of nutrition and shelter rely on healthy ecosystems and a stable climate system [14]. The threshold level of the ecological meta-capability should be defined in reference to real ecological system 
thresholds. These ecosystem thresholds should be avoided surpassing because of their crucial role in the support of basic human capabilities [14] (p. 162):

'Policies that promise to stay within the ecological limits of justice will, at a minimum, establish capability ceilings that protect the resilience of ecosystems they influence. [ ... ] To develop a more scientifically demanding and nuanced form of policy evaluation would entail establishing capability ceilings in more direct relation to ecological thresholds so as to ensure the capability protections a policy provides will prevent the activities that push an ecosystem beyond the point at which a collapse in its functioning occurs'. [14] (p. 163)

A key difficulty for this threshold approach is to define the precise ecosystem threshold levels. An additional complication is that multiple ecosystem states are possible, and most crucially, different actors benefit from different socio-ecological system states. Crossing socio-ecological system thresholds can alter the ecosystem services provided, which will affect different people differently. Some ecosystem services can be argued to be valuable to all humans, such as livable temperature levels and sufficient rain for food production. Still, socio-economic inequalities cause differentiated vulnerabilities. Some people are able to afford air-conditioning, irrigation systems or high-quality food imports, while others do not have access to these opportunities. Holland does notice distributive effects of ecosystem changes, but her writing about avoiding collapse of 'an ecosystem' beyond its thresholds does not match the co-evolutionary understanding of ecosystems as contested and co-evolving.

The Haringvliet controversy discussed next reveals that the choice for either a resilient fresh or a resilient brackish ecosystem is a political one. Adaptation responses can support 'resilience' as in bouncing back to the same socio-ecological system, or support transformative responses that do not recreate the current system [45,46]. Moreover, at the water system level, uncertainties about impacts of responses and future climate scenarios cause difficulties for establishing precise thresholds in adaptation policy.

\section{Case: The Contested Restoration of Estuarial Dynamics in the Haringvliet}

This section explains the research design (Section 3.1) and introduces the Haringvliet controversy (Section 3.2). Next, it addresses disagreements about the most desirable ecosystem state (\$3.3), decades-long negotiations about the chloride level threshold (Section 3.4) and the co-evolutionary changes that unsettle temporary compromises (Section 3.5). Examples of the latter are changes in public opinion, changing investment and land use patterns and unexpected changes in the natural system due to engineering interventions and anthropogenic climate change.

\subsection{Research Design and Methodology}

This philosophical study is informed by qualitative interpretative research [70,71]. As earlier studies in Science and Technology Studies have shown, detailed empirical descriptions can generate knowledge about how societies handle water management dilemma's and inform policymaking [32,33,70-74]. Philosophical research and especially ethics can benefit from empirical insights to gain a more fine-grained understanding of real-world controversies, select the most salient approaches and even further develop philosophical theories $[19,59,75]$.

The case study is based on interviews, observations and secondary literature. The author followed policy processes about the future of the Dutch South-West Delta (most notably, meetings of the Gebiedsagenda Zuidwestelijke Delta 2050), spoke to fourteen expertinformants and stakeholders and studied policy documents. Interviews were conducted according to the principles of prior and informed consent. Interview notes were documented, audio recordings transcribed and data stored, protected and anonymized. The combination of in-depth interviews, ethnographic observations and multiple field visits to the Haringvliet's surrounding farmland and nature reserves informed the conceptual philosophical analysis and steered the research direction in an iterative manner. Conclu- 
sions are of an interpretative nature and do not aim to provide final conclusions about the controversy. Rather, the goal is to gain insights by describing the Haringvliet controversy, the issues around establishing ecological limits and the difficulties with using these limits to justify philosophical limits or policy targets. In this way, the research also shows the relevance of combining philosophical research with empirical social scientific data.

\subsection{The Haringvliet Estuary Turned Fresh-Water Lake}

Since humans started to inhabit the low-lying peat marshes of The Netherlands, the Dutch Delta has become one of the most heavily modified deltas in the world [33,35]. One of the major waterbodies part of the Dutch delta is the Haringvliet, a 10,382 ha fresh-water lake that used to be a brackish estuary [76]. All the rainwater that falls in the Rhine-Meusse watershed eventually flows to the North Sea. (Details of the water management regime: The discharge volume of the Haringvliet sluices depends primarily on the river discharge of the Rhine at Lobith, near the German border. Between 2000 and 2011, it was measured that 24.2-30.4\% of the Rhine discharge discharged into the sea via the Haringvliet sluices [77]. The average discharge of the Rhine river is $1960 \mathrm{~m}^{3} / 2$ and the catchment area is around $170,000 \mathrm{~km}^{2}$. The average discharge of the Meusse river is significantly smaller, $230 \mathrm{~m}^{3} / \mathrm{s}$, and the catchment area is around $\left.33.000 \mathrm{~km}^{2}[76,77]\right)$.

After a major coastal flood in 1953 that led to over 1800 deaths, a series of dams and storm barriers called the Delta Works were constructed (Figure 1). The plan to close off the sea-arms of the Delta had three objectives: increasing the fresh water availability, improving the connectivity between the separate islands of Zeeland and Zuid Holland and ensuring flood safety [26]. The tidal dynamics of the once-open sea-arm disappeared with the construction of the Haringvliet dam (1958-1971; several kilometers of dam, 17 sluices and a ship lock) [74]. Sectors that reaped the benefits of these changes were fresh-water agriculture, transportation companies and the Port of Rotterdam. Moreover, citizens were better protected against flooding and profited from economic development in the region. Stakeholders on the losing end of this landscape modification were the fish and shellfish sector, nature protection organizations and the ecology of the brackish delta itself [78]. In the Haringvliet, a brackish wetland was lost, and with it, rare species and a unique landscape [79]. The water changed from a brackish/saline to a predominantly fresh water system.

The Haringvliet is a crucial component of the larger Rhine river systems' ecology. Water quality measures have helped to strengthen the fish populations [78]. Still, due to all the modifications in the river system, the Rhine is put on a lifeline and current fish stocks are not sustainable for the future [78-80]. Migratory species such as salmon face barriers on their migration routes. The opening of the Haringvliet sluices during the migrating season could help fish such as salmon to reach their breeding grounds in Germany and Switzerland. Moreover, an ecological transition zone with a gradual shift from saline to fresh water supports migrating species that need 'softer borders'.

The creation of brackish transition zones or the more ambitious reintroduction of tidal dynamics is contested. Since the closing of the estuary, fresh-water agriculture intensified, and farmers shifted to more capital-intensive and sensitive crops. These changes heightened their dependence upon the abundant fresh-water availability. The fresh-water usage of other sectors such as drinking water for the growing population and industry have also increased over time. In short, the newly created freshwater reservoir is used by old and new stakeholders that have come to rely on and feel entitled to a fresh Haringvliet. 


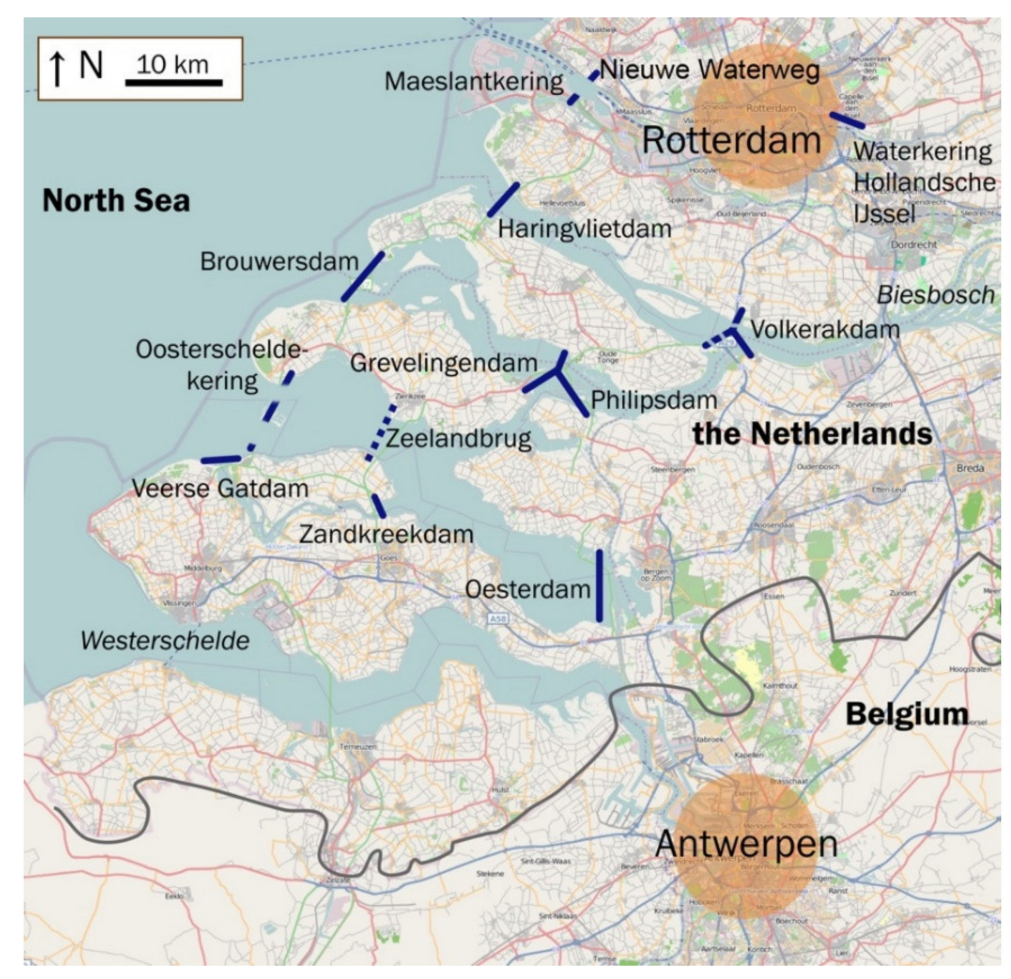

Figure 1. Overview of Dutch Delta Works. Adapted CC BY-SA map originally by OpenStreetMap.

\subsection{Fresh or Saline: What Is the Most Desirable Socio-Ecological System State?}

What is seen as the most desirable socio-ecological system state varies per stakeholder and over time [26]. Debates about the saline intrusion are related to policy shifts in Dutch water management and changes in the general public opinion towards the environmentshowing the relevance of co-evolutionary analysis. After the 1953 disaster, flood safety became the primary and almost uncontested objective behind the expensive delta works that were constructed between 1958 and 1987 [35,72]. The biodiversity losses and negative impact on the fish and shellfish sector were known, but they were both underestimated and considered negligible in comparison to the trauma of the disaster of 1953 [74]. The long construction phase of all the Delta Works coincided with a rise in environmental awareness in Dutch water management [72,81,82]. In the 1970s, the detrimental ecological effects of the closing of the Haringvliet became visible. Fishermen and environmental groups protested together against the planned closure of another sea-arm: the Eastern Scheldt. The protests were successful and the design was adapted from a permanently closed dam to a flexible storm-barrier, which meant that the tidal dynamics could stay [72]. This 'ecological turn' in the design of the Eastern Scheldt barrier is often mentioned in the literature as an example of value change and new integration of ecology into civil engineering [72,81,82]. However, this is not the only shift that can be observed in the Dutch South-West Delta.

The rise of environmentalism kept ascending roughly between 1960 and 2000. Ambitious environmental policy was developed in the form of the RIO declaration and the European Water Framework Directive. In 1986, Plan Ooijevaar was presented with a vision for restoration of the Dutch river systems. During this time, there was societal support for Rijkswaterstaat to commence investigating the restoration of tidal dynamics in the Haringvliet. Nevertheless, re-introducing tidal dynamics in the Haringvliet was fiercely debated and an alternative plan emerged: Getemd Getij (tamed tides). This plan involved creating a saline gradient transition zone to accommodate the migration of fish [26] (p. 889). After fierce political discussions about the 1994 Environmental Impact Analysis, the final 2000 policy decision was adopted (Het Kierbesluit). By now, the plan only included the partial restoration of tidal dynamics [83]. 
The plans to restore tidal dynamics encountered resistance, because the social system had also adapted to the new situation with a closed Haringvliet (Figure 2). Freshwater agriculture intensified and became more dependent upon the Haringvliet as a freshwater reservoir. Other factors that fueled the controversy were spill-over effects due to low food prices, new 'delta nature' projects that involved buy-outs of farmland and the drought of 2003. Climate change and the risk of decreasing freshwater availability entered the policy agenda more prominently [26] (p. 892). Due to negotiations about compensation measures and construction delays, the implementation of the 2000 government decision Het Kierbesluit was postponed several times. Between 2008 and 2010, after an intensive lobby by farmer organizations and the election of a new government, the project to restore the Haringvliet almost came to an halt altogether [47].

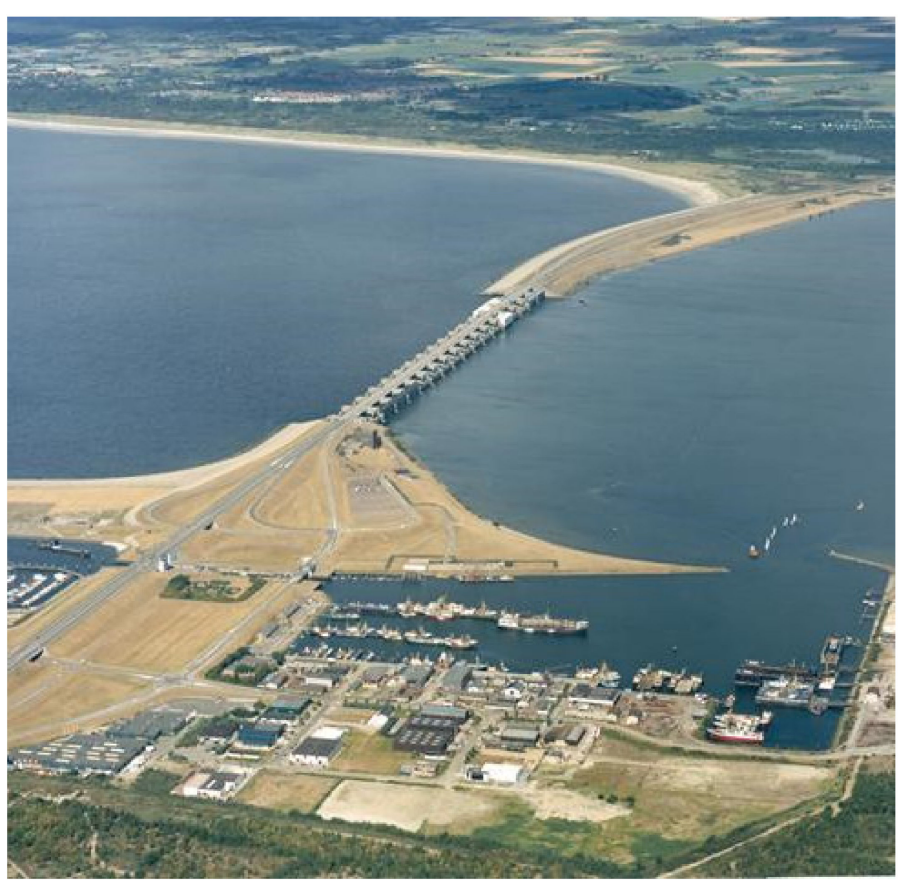

Figure 2. Haringvlietdam from the sky. Source: Rijkswaterstaat Beeldbank. Image reproduced with permission of Rijkswaterstaat.

Only after international pressure from the International Commission on Protection of the Rhine and the European Union, it was decided to continue with the implementation of the 2000 Kierbesluit $[84,85]$. The opening of the Haringvliet dam is a vital part of the chain of ecological measures meant to restore the Rhine and bring back the salmonother countries had already invested funds in ecological measures that would be less effective if The Netherlands did not do its turn. After 2010, the rationale behind the partial dam opening appealed more to values such as diplomatic trustworthiness and solidarity in the transboundary river system, than to the former devoted aspiration to restore the Haringvliet. The current version of Het Kierbesluit contains more humble ecological ambitions that are no longer mentioned as the 'first step' towards the full restoration of tidal dynamics as was part of the first plans, but functions as a stand-alone measure to improve living conditions for migratory species.

In sum, over the course of time, two distinct shifts occurred in the management of the Haringvliet. The first was part of the broader ecological turn in Dutch water management that was reflected in policy plans about restoring tidal dynamics. The second shift occurred after the 2000s when there was a growing awareness of potential future limits of freshwater availability and a re-prioritization of economic interests over ecological interests. The people involved in the project experienced firsthand the importance of fluctuating public opinion and policy priorities over time. There were 33 years between the initial plan 
making for restoration of tidal dynamics, and the first time that the sluices were actually opened for a short while was in 2019.

\subsection{Contested Threshold: Saline Intrusion in the Haringoliet}

The outcome of this long negotiation process is that the sluices of the Haringvliet can open under the condition that (1) the Rhine's discharge level is above $1200 \mathrm{~m}^{3} / \mathrm{s}$ or $1500 \mathrm{~m}^{3} / \mathrm{s}$, depending on the tides; (2) the salt water does not pass the town of Middelharnis on the map; (3) chloride levels at the drinking water inlets do not exceed $300 \mathrm{mg} / \mathrm{L}$. The sluices can only open when there is sufficient discharge to flush the Haringvliet with fresh water to prevent salt-water intrusion beyond the dictated line on the map (Figure 3). In previous plans, the line was drawn further inland beyond the Tiengemeten island, but in those scenarios, another drinking-water inlet had to be relocated, significantly increasing the costs. The large economic costs of opening the sluices were related to compensatory measures that needed to be implemented to secure fresh water for drinking water, industry and agricultural irrigation.

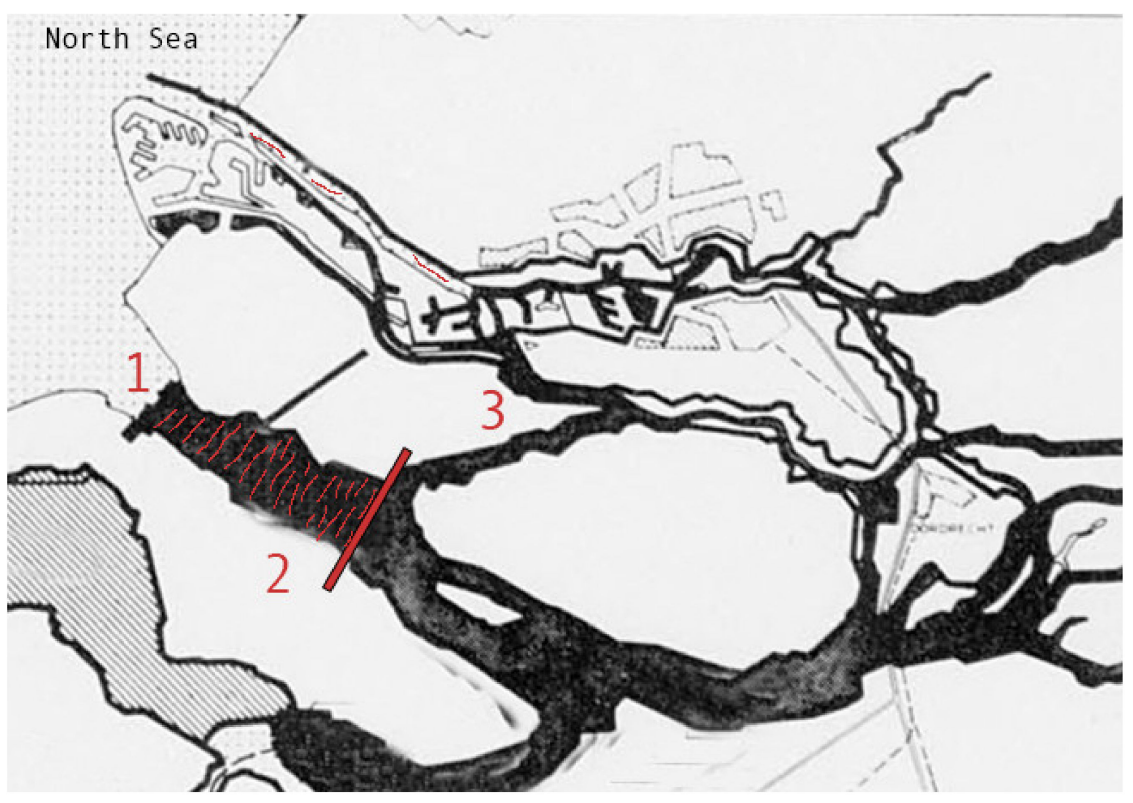

Figure 3. (1) The Haringvliet Dam. (2) In red, the negotiated saline threshold in the Haringvliet near the town of Middelharnis. (3) Spui waterway, risk of backward salt-water intrusion. Black parts represent fresh water, white/dotted parts saline water. CC BY-SA adapted map from Wikimedia Commons; original commissioner: House of Representatives, The Netherlands.

Since 2019, after several implementation delays due to regional protests, the managing agency, Rijkswaterstaat, implementing agency of the Dutch Ministry of Infrastructure and Water Management, is experimenting with small openings and monitoring the effect on the salt-water intrusion [86]. The agency uses adaptive water management techniques with a focus on experimenting and learning, but have to stay within the agreed upon chloride ranges at all costs. If there would be an accidental 'saline bell' that floats further than the agreed upon line, or worse, influences a fresh-water inlet, the agency may lose the hard-won trust of local actors that were against the Kierbesluit in the first place. Therefore, Rijkswaterstaat operates very carefully.

The Haringvliet controversy shows that different actors favor different socio-ecological system states over time: fresh versus brackish water. Moreover, within the current freshwater system, the exact ecological thresholds such as river discharge and chloride levels are meticulously debated. Although neighboring farmers are quite content with the current management regime, many still conceive of the partial dam-opening as a luxurious and costly measure with uncertain benefits. Environmental groups, on the other hand, are not 
satisfied with the small opening and criticize the lack of ambition from Rijkswaterstaat to further improve tidal dynamics. Although beneficial effects of the opening of the sluices on fish stock and fish migration are carefully celebrated, they are uncertain and currently being monitored by Rijkswaterstaat and universities. All in all, the Kierbesluit policy decision is the outcome of a long negotiation process and a peculiar and unstable compromise.

\subsection{Continuous Change: The Co-Evolution of the Dutch Delta}

The closing of the Haringvliet is difficult to reverse completely because the dam's construction influenced the co-evolutionary process of the Dutch South-West Delta. Two examples of such changes will be discussed next: changes in land use and investment patterns and changes due to unintended consequences of engineering artefacts and humaninduced climate change.

\subsubsection{Path Dependency: Investment and Land Use Patterns}

Since the Haringvliet dam closed, investment decisions have been based upon the artificially created high-quality freshwater reservoir. After the food shortages during World War II, the Dutch government strived towards self-sufficiency and increased food production. Private investments were supported by government policy oriented at maximizing agricultural output. Increased mechanization, land consolidation and upscaling all led to the current situation in which The Netherlands is a large net-food exporter. Many farms transformed into large agricultural companies with the associated debt and dependency on banks. Farmers are invested in the fresh-water system, also literally: the restructuring of the island of Goerree-Overflakkee and the improved drainage system is still being paid in installments by farmers in the region.

Acknowledging the influence of past policies on the current situation is critical to understand different justice claims in the Haringvliet controversy. A conclusion from a co-evolutionary analysis could be that future public and private investments need to avoid strengthening harmful institutional and technological lock-ins. Climate-proof production and healthy soils are also important to farmers; still, interviewees said they were only experimenting on small plots. There are barriers in the wider social system: upscaling these 'natural' techniques to all their hectares would only be possible if food prices increase throughout the entire internal market in Europe. A farmer: 'It is no longer possible to live from only five hectares, you need a field of fifty hectares now. The conditions for our business case have changed'.

\subsubsection{Shifting Systems: Impacts of Engineering Artefacts and Climate Change}

The Dutch Delta system is not static and requires constant human maintenance in the form of drainage and flushing in order to stay fresh. Unintended consequences of the Haringvliet dam's closure were changes in sedimentation and erosion patterns. The higher stream velocity deepens the Spui waterway that connects the Haringvliet to another sea arm, the Nieuwe Waterweg. As a consequence, the risk of 'backward' salt-water intrusion has increased. The Nieuwe Waterweg sea arm is not closed by a permanent dam because it is home to the Port of Rotterdam. The largest harbor of Europe is a powerful stakeholder that requires deep shipping routes free from obstacles. Salt water is heavier than fresh water and travels further inland through the deep waterways. In Dutch, this phenomenon is called the 'salty tongue'. The impact on the Haringvliet is that even when the Haringvliet dam is fully closed, in certain weather conditions, the salty water may still enter the Haringvliet through the Spui back entrance. A co-evolutionary perspective can include unexpected shifts in the natural system, such as erosion, that change the overall system dynamics. Moreover, the socio-ecological system of the Dutch Delta is part of the larger hydrological and climate system. If climate change continues, all the discussions about the Haringvliet dam opening may become superfluous.

Due to climate change, in the long term, the discharge pattern of the Rhine river is expected to become more variable, with higher and lower extremes [87-91]. In the Rhine 
watershed, researchers already measured a change between 1981 and 2010: precipitation decreased with $80 \mathrm{~mm}$ and evaporation increased with $70 \mathrm{~mm}$ [90]. The Royal Dutch Meteorological Institute (KNMI) translates the IPCC scenarios to the Dutch context with the KNMI'14 scenarios [89]. In all KNMI'14 scenarios, the chance of discharges above $12.000 \mathrm{~m}^{3} / \mathrm{s}$ increases from once every 100 years to once every 30 years [88]. In the more extreme scenarios, beyond 2085, this can even be once every ten years [88]. Lower discharges are currently only projected to occur with the high-end scenarios. The reason is that the increased melt-water from the alps temporarily levels out the decreased precipitation in the summer.On the long term, however, if climate change accelerates, extremely low discharges are expected to occur more frequently [91]. In 2023, the KNMI'23 scenarios will be adjusted to the sixth IPCC assessment report published in 2021 [89].

Low river discharges can contribute to salt-water intrusion in the Dutch Delta. The threshold for the Kierbesluit measure is set at $1500 \mathrm{~m}^{3} / \mathrm{s}$ discharge with high tide, because this is the amount required to prevent the salt water to intrude too far into the waterways, according to the negotiated standards. If there is less water available for flushing the Haringvliet and the Nieuwe Waterweg, there will be fewer days that the Haringvliet sluices can be opened under the conditions of the Kierbesluit. This reduces the effectivity of the Haringvliet Kierbesluit measure in its current form [77]. Besides, translating recent findings about the risk of accelerated melting of the Antarctic ice sheet, researchers find that saltwater intrusion may also intensify because of sea level rise. In combination with increased fresh water demand, this reduces the freshwater availability [92,93]. Moreover, with higher sea levels, the Delta works storm surge barriers will need to close more frequently until at one point, all must close permanently [92].

These changes in local ecosystems and the global climate system lead to continuous balancing acts instead of a stable equilibrium. In the future, large amounts of public and private resources may be required to sustain current functionings in the region. As climate impacts materialize, the balance between what is possible in the Dutch Delta and what kind of land usages the Dutch taxpayers are willing to sustain may change. The risk of more frequent droughts strengthens the wish of fresh-water farmers to maximize fresh-water availability in the region. Therefore, they contest efforts to salinize or create brackish transition zones. Yet, more questions can be raised: not all crops are as water intensive and sensitive to saline water as tulip flower bulbs, a typical high-value cash crop in the region. An interviewee stated rhetorically: 'Where is it written that they [farmers] have the right to grow tulips?' Whether adaptation responses should focus on increasing fresh-water storage or support accommodating tidal dynamics and associated saline livelihoods is topic of fierce debate. Besides salt-water intrusion, the risk of accelerated sea level rise puts the question of long-term habitation of the coastal low-lying marshes on the table [92]. The maintenance of all current engineering artefacts is very costly. Moreover, these barriers also obstruct the full restoration of the Rhine river system [78,91]. Scenarios and imaginaries vary between hold-the-line policies, land reclamations and advancing to sea or resorting to managed retreat/managed realignment options [93]. Difficult trade-offs will have to be made to establish thresholds and balance values such as ecology, economy and safety.

In sum, future stressors due to (un)foreseen social or natural developments will alter the precarious balance between different actors in the Haringvliet. Hence, the Kierbesluit compromise, the result of decades-long negotiations, will probably only be a temporary compromise.

\section{Discussion}

According to the IPCC definition, climate adaptation involves anticipatory action to 'moderate harms' and reap 'beneficial effects' of changes in social and natural systems. The more frequent occurrence of droughts and a rising sea level will put pressure on today's negotiated compromises, such as the Haringvliet chloride level compromise. In the future, next to climate impacts, more controversies about eco-system state shifts can be anticipated. The landscapes in which we live keep changing, so establishing ecological thresholds 
means taking part in continuous negotiations. These adaptation politics are shaped by social and ecological path dependencies. Next in the discussion, the implications of the challenge of co-evolution for the capability approach to justice are explained.

\subsection{Implications for the Capability Approach}

The analysis of the Dutch Delta as a co-evolving socio-ecological system has implications for the capability approach to justice. For instance, the question which species or kind of 'nature' to protect is debatable. Fresh or brackish ecosystems support different species and different kinds of human livelihoods. The artificially created Haringvliet fresh water lake contains more species, while the former Haringvliet estuary was home to rarer species that flourished in brackish water. The Haringvliet dam also obstructs the flourishing of migratory species (and associated livelihoods, such as salmon fishing, which almost disappeared in the Rhine river). Looking at the controversy from the level of European governance, it can be justified that the brackish water and migratory species earn protection. Not only for the salmon, but because healthy rivers are the backbone of human civilization. Clean, safe and biodiverse Rhine water will also contribute to the overall development of the region, just as infrastructures for navigation do. Nevertheless, local landowners may reach a different conclusion. The agricultural sector has come to rely on the Haringvliet as a fresh-water reservoir. They fear the shrinking availability of fresh water in the future due to climate change and increases in demand. In short, it is debatable whether the notion of 'Sustainable Ecological Capacity' requires thriving salmon stocks or the protection of the existing fresh-water system that is the Haringvliet.

Adaptation responses in the Dutch South-West delta can either support the existing fresh-water system ecology or the transformation towards more saline ecosystems and livelihoods. In terms of the capability approach, this means that different socio-ecological system states allow for the development of different functionings and capabilities. Abstract basic capabilities such as 'life' and 'bodily health' can be protected in multiple scenarios, although having the freedom to decide what kind of livelihood one wants to realize (functionings) is necessarily constrained by developments in the larger socio-ecological system. Ecological limits change over time and can be the topic of fierce political debates, as the Haringvliet controversy illustrated. Moreover, what seem like marginal 'technical' policy discussions about dyke width or changes in the chloride level actually present normative choices [46,47]; in local climate adaptation, the devil can be in the details.

The challenge of co-evolution also entails acknowledging the influence of changes in adjacent techno-social systems upon the development of the Haringvliet controversy. First of all, public opinion and policy priorities in the water management regime changed during the thirty-year negotiation process about opening the sluices. Second, path-dependencies created by past investments, engineering artefacts and policies supporting one type of agriculture shaped the current state of the Haringvliet and its vulnerability to climate risks. At last, unintended consequences such as local erosion or global climate change will keep uprooting today's contested compromise about salt-water intrusion: Het Kierbesluit.

To conclude, the Haringvliet controversy shows that it is not possible to rely on 'straightforward' ecological thresholds for establishing ecological limits. There is disagreement about the most desirable system state to protect. Subsequently, establishing the substantive precondition of the meta-capability Sustainable Ecological Capacity requires additional political and normative decisions. In these negotiations, political inequality and power distributions among stakeholders matter. Capabilities need to be specified and prioritized at the local level; therefore, fairness in democratic decision-making processes is critical.

\subsection{Implications: Integrating Procedural Justice}

The challenge of co-evolution demonstrates the need to pay additional attention to procedural justice in adaptation research and policy. There are ways to include procedural justice in a capabilities-based framework. To start, in Allocating the Earth, Holland does not 
only discuss ecological limits, but also the precondition of sufficient political equality in the form of political capabilities $[8,19,20]$. Participation and forms of deliberation are frequently mentioned as solutions to advance procedural justice. Yet, democratic theorists argue that certain background conditions need to be fulfilled to realize genuine deliberation. For instance, people need sufficient income and resources to develop the basic capacities for effective political participation [14,94]. Equality of political participation is also reflected in Nussbaum's list in the form of the capability 'political control over your environment' [95]. This notion is further developed by Holland as a concept for procedural justice in local climate adaptation [19]. She defines 'political capabilities' as having the power to influence adaptation decisions' [19].

Along a different line of reasoning, but without making use of Nussbaum's universal list of basic capabilities, Srinivasan arrives at a similar conclusion as Holland [20]. According to him, Sen's open-ended deliberative version does require non-procedural guarantees of political equality. The reason is that Amartya Sen relies on democratic deliberation to decide what the most valuable capabilities are (public reason). Subsequently, freedom and fairness in democratic decision making are key in Sen's writing. Hence, according to Srinivasan, Sen would also have to support minimal preconditions that guarantee genuine deliberation. It is not necessary to defend a full list of capabilities, but it is required to secure sufficient political capabilities in capability theories.

Srinivasan mentions political capabilities, because he is concerned with actual opportunities for political participation. Hinting at the consequentialist properties of the capability approach, he states: 'it protects equality of substantive political freedom seen properly in the perspective of capabilities, not merely civil liberties and political rights' [20] (p. 457). How exactly to integrate procedural justice in climate adaptation ethics requires further research. Still, as a start, the ideal of striving towards equality of political influence provides an interesting intersection between Nussbaum and Sen's approach to the capability approach.

A more pragmatic argument for focusing on procedural justice in further research is that even if philosophical academic argumentation could identify the ideal list of basic capabilities, or meta-criteria for sustainability or ecological limits, there still will be disagreement among stakeholders that practitioners must respond to on the ground [19]. Climate adaptation is about landscape changes that may spark political conflict. Hence, we should anticipate and start more discussions about legitimate expectations and just transitions in climate adaptation $[96,97]$. Moreover, due to normative uncertainties it is important to keep options open. Future generations may prioritize capabilities differently than current populations [98]. The empirical case study of the Haringvliet controversy, with its decades-long negotiations and contested thresholds, supports these theoretical reflections.

\subsection{Applicability and Limits}

The capability approach does not provide a complete theory to address adaptation justice. It can be used to provide an alternative assessment of public policy on different terms than, for example, the utilitarian cost-benefit analysis. Moreover, using capabilities as an analytical lens helps to focus on outcomes of policies and how these are shaped by personal, social and environmental conversion factors. This stands in contrast to approaches that distribute resources and liberties independent of peoples' context. In line with methodological pluralism, the goal is not to provide the 'best' method for policy assessment, but to test multiple methods and compare the different results $[99,100]$. Further research is also needed to investigate complementary perspectives or extensions of the capability approach that go beyond human functioning and address the intrinsic value of ecosystems and other species.

Debates about changing thresholds in socio-ecological systems take place anywhere, although the circumstances and topic of the conflict will be different. Controversies to which the perspective of this paper can be of relevance are discussions about changes in landscape functions or the creation of new water quality or biodiversity targets. Compa- 
rable debates in the Dutch Delta, for instance, revolve around changes in the water table or initiatives to start de-poldering $[33,101,102]$. The generalizability of this local climate adaptation case is a question to decide for researchers acquainted with other policy contexts. The context described is located in North-Western Europe, in a liberal democracy and a rich industrialized country. At the global level, Eurocentric thinking should be avoided, especially considering the grave inequality in climate vulnerability between the Global North and Global South. Still, there may be observations and theoretical reflections that also have explanatory value in other contexts. In recent academic thinking, there is also discussion about nature conservation versus understanding ecosystems as co-evolving and dynamic systems [17,103,104].

The relevance of integrating empirical research into the discipline of philosophy is that lessons from real-life controversies can help to improve theory as well. Instead of abstract theorizing about possible future conflicts, we can learn from ongoing natural resource management controversies to direct philosophical research and develop an ethics of climate adaptation.

Funding: This research received no external funding.

Institutional Review Board Statement: Not applicable.

Informed Consent Statement: Informed consent was obtained from all subjects involved in the study. Data Availability Statement: Not applicable.

Acknowledgments: I want to thank all interviewees for their time and for sharing their perspectives. Their names have been anonymized. Additionally, I thank fellow researchers and former colleagues I have had conversations with about the Dutch South-West Delta in the past. At last, I am grateful for the comments of two anonymous reviewers and the colleagues who were so kind to read previous drafts: Neelke, Udo, Sara, Ben and Charlotte.

Conflicts of Interest: The author declares no conflict of interest.

\section{References}

1. Masson-Delmotte, V.; Zhai, P.; Pirani, A.; Connors, S.L.; Péan, C.; Berger, S.; Caud, N.; Chen, Y.; Goldfarb, L.; Gomis, M.I.; et al. (Eds.) IPCC AR6 Climate Change 2021: The Physical Science Basis. Contribution of Working Group 1 to the Sixth Assessment Report of the Intergovernmental Panel on Climate Change; Cambridge University Press: Cambridge, UK, 2021.

2. Paavola, J.; Adger, W.N. Fair adaptation to climate change. Ecol. Econ. 2006, 56, 594-609. [CrossRef]

3. Heyward, C. Ethics and Climate Adaptation. In The Oxford Handbook of Environmental Ethics; Oxford University Press: Oxford, UK, 2017; pp. 474-486. [CrossRef]

4. O'Brien, K.; St. Clair, A.L.; Kristoffersen, B. Climate Change, Ethics and Human Security; O’Brien, K., St. Clair, A.L., Kristoffersen, B., Eds.; Cambridge University Press: Cambridge, UK, 2010; ISBN 9780521197663.

5. Field, C.B.; Barros, V.R.; Dokken, D.J.; Mach, K.J.; Mastrandrae, M.D.; Bilir, T.E.; Chatterjee, M.; Ebi, K.L.; Estrada, K.J.; Genova, R.C.; et al. (Eds.) IPCC Climate Change 2014: Impacts, Adaptation, and Vulnerability. Part A: Global and Sectoral Aspects. Contribution of Working Group II to the Fifth Assessment Report of the Intergovernmental Panel on Climate Change; Cambridge University Press: Cambridge, UK, 2014.

6. Siders, A.R.; Ajibade, I.; Casagrande, D. Transformative potential of managed retreat as climate adaptation. Curr. Opin. Environ. Sustain. 2021, 50, 272-280. [CrossRef]

7. Rulleau, B.; Rey-Valette, H.; Clément, V. Impact of justice and solidarity variables on the acceptability of managed realignment. Clim. Policy 2017, 17, 361-377. [CrossRef]

8. Schlosberg, D. Climate Justice and Capabilities: A Framework for Adaptation Policy. Ethics Int. Aff. 2012, 26, 445-461. [CrossRef]

9. Doorn, N.; Gardoni, P.; Murphy, C. A multidisciplinary definition and evaluation of resilience: The role of social justice in defining resilience. Sustain. Resilient Infrastruct. 2018, 9689, 112-123. [CrossRef]

10. Johnson, C.A. Governing climate displacement: The ethics and politics of human resettlement. Environ. Politics 2012, 21, 308-328. [CrossRef]

11. Kronlid, D. Climate Change Adaptation and Human Capabilities: Justice and Ethics in Research and Policy; Palgrave Macmillan: New York, NY, USA, 2014.

12. Sheller, M.; Leon, Y. Uneven socio-ecologies of Hispanolia: Asymmetric capabilities for climate adaptation in Haiti and the Dominican Republic. Geoforum 2016, 73, 32-46. [CrossRef]

13. Holland, B. Justice and the environment in Nussbaum's "capabilities approach": Why sustainable ecological capacity is a meta-capability. Political Res. Q. 2008, 61, 319-332. [CrossRef] 
14. Holland, B. Allocating the Earth: A Distributional Framework for Protecting Capabilities in Environmental Law and Policy; Oxford University Press: Oxford, UK, 2014; ISBN 0021-5392.

15. Holland, B. Ecology and the Limits of Justice: Establishing Capability Ceilings in Nussbaum's Capabilities Approach. J. Hum. Dev. 2008, 9, 401-425. [CrossRef]

16. Holland, B. Environment as Meta-capability: Why a Difnified Human Life Requires a Stable Climate System. In Ethical Adaptation to Climate Change; Thompson, A., Bendik-Keymer, J., Eds.; The MIT Press: Cambridge, MA, USA, 2012; pp. $145-164$.

17. Dryzek, J.S.; Pickering, J. The Politics of the Anthropocene; Oxford University Press: Oxford, UK, 2018; ISBN 9780198809616.

18. Schlosberg, D. Reconceiving Environmental Justice: Global Movements and Political Theories. Environ. Polit. 2004, 13, 517-540. [CrossRef]

19. Holland, B. Procedural justice in local climate adaptation: Political capabilities and transformational change. Environ. Polit. 2017, 26, 391-412. [CrossRef]

20. Srinivasan, S. No Democracy without Justice: Political Freedom in Amartya Sen's Capability Approach. J. Hum. Dev. 2007, 8, 457-480. [CrossRef]

21. Folke, C. Social-ecological systems and adaptive governance of the commons. Ecol. Resour. 2007, 22, 14-15. [CrossRef]

22. Refulio-Coronado, S.; Lacasse, K.; Dalton, T.; Humphries, A.; Basu, S.; Uchida, H.; Uchida, E. Coastal and Marine Socio-Ecological Systems: A Systematic Review of the Literature. Front. Mar. Sci. 2021, 8, 1-17. [CrossRef]

23. Gual, M.A.; Norgaard, R.B. Bridging ecological and social systems coevolution: A review and proposal. Ecol. Econ. 2010, 69, 707-717. [CrossRef]

24. Cote, M.; Nightingale, A.J. Resilience thinking meets social theory: Situating social change in socio-ecological systems (SES) research. Prog. Hum. Geogr. 2012, 36, 475-489. [CrossRef]

25. Minnes, S.; Gaspard, V.; Loring, P.A.; Baulch, H.; Breen, S.P. Transforming conflict over natural resources: A socio-ecological systems analysis of agricultural drainage. Facets 2020, 5, 864-886. [CrossRef]

26. Marks, P.K.; Gerrits, L.M.; Bakker, S.; Tromp, E. Explaining inertia in restoring estuarine dynamics in the Haringvliet (The Netherlands). Water Policy 2014, 16, 880-896. [CrossRef]

27. Jasanoff, S. States of Knowledge: The Co-Production of Science and the Social Order; Routledge: London, UK, $2004 ;$ ISBN 0203413849.

28. Melsen, L.A.; Vos, J.; Boelens, R. What is the role of the model in socio-hydrology? Discussion of "Prediction in a socio-hydrological world". Hydrol. Sci. J. 2018, 63, 1435-1443. [CrossRef]

29. Wesselink, A.; Kooy, M.; Warner, J.F. Socio-hydrology and hydrosocial analysis: Toward dialogues across disciplines. Wiley Interdiscip. Rev. Water 2017, 4, e1196. [CrossRef]

30. Boelens, R.; Hoogesteger, J.; Swyngedouw, E.; Vos, J.; Wester, P. Hydrosocial territories: A political ecology perspective. Water Int. 2016, 41, 1-14. [CrossRef]

31. Latour, B. Facing Gaia-Eight Lectures on the New Climatic Regime; Polity: Cambridge, UK, 2017.

32. Van der Vleuten, E.; Disco, C. Water wizards: Reshaping wet nature and society. Hist. Technol. 2004, 20, 291-309. [CrossRef]

33. Zegwaard, A.; Wester, P. Inside Matters of Facts: Reopening Dams and Debates in the Netherlands. Water Altern. 2014, 7, 464-479.

34. Bijker, W. Do we live in water cultures? A methodological commentary. Soc. Stud. Sci. 2012, 42, 624-627. [CrossRef]

35. Disco, C.; van der Vleuten, E. The politics of wet system building: Balancing interests in dutch water management from the Middle Ages to the present. Knowl. Technol. Policy 2002, 14, 21-40. [CrossRef]

36. Norgaard, R.B. Development Betrayed: The End of Progress and a Coevolutionary Revisioning of the Future; Taylor \& Francis: New York, NY, USA; Routledge: London, UK, 2006; ISBN 0415068614.

37. Norgaard, R.B.; Kallis, G.; Kiparsky, M. Collectively engaging complex socio-ecological systems: Re-envisioning science, governance, and the California Delta. Environ. Sci. Policy 2009, 12, 644-652. [CrossRef]

38. Van Staveren, M.F.; Van Tatenhove, J.P.M. Hydraulic engineering in the social-ecological delta: Understanding the interplay between social, ecological, and technological systems in the Dutch delta by means of "delta trajectories". Ecol. Soc. 2016, 21, 8. [CrossRef]

39. Van Der Werf, K.; Gilissen, H.K.; Kleinhans, M.; van Rijswick, M. On dynamic naturalness, static regulation and human influence in the Ems-Dollard estuary. Int. J. Water Resour. Dev. 2020, 1-20. [CrossRef]

40. Jeffrey, P.; Mcintosh, B.S. Description, diagnosis, prescription: A critique of the application of co-evolutionary models to natural resource management. Environ. Conserv. 2006, 33, 281-293. [CrossRef]

41. Fainstein, S. Resilience and justice. Int. J. Urban Reg. Res. 2015, 39, 157-167. [CrossRef]

42. Eriksen, S.H.; Nightingale, A.J.; Eakin, H. Reframing adaptation: The political nature of climate change adaptation. Glob. Environ. Change 2015, 35, 523-533. [CrossRef]

43. O'Brien, K.; Eriksen, S.; Nygaard, L.P.; Schjolden, A. Why different interpretations of vulnerability matter in climate change discourses. Clim. Policy 2007, 7, 73-88. [CrossRef]

44. Pelling, M. Adaptation to Climate Change from Resilience to Tranformation; Routledge: London, UK, $2011 ;$ ISBN 1134022026.

45. Dewulf, A.; Karpouzoglou, T.; Warner, J.F.; Wesselink, A.; Mao, F.; Vos, J.; Tamas, P.; Groot, A.E.; Heijmans, A.; Ahmed, F.; et al. The power to define resilience in social-hydrological systems: Toward a power-sensitive resilience framework. WIREs Water 2019, 6, e1377. [CrossRef]

46. Keessen, A.M.; Vink, M.; Wiering, M.A.; Boezeman, D.; Ernst, W.; Mees, H.; Van Broekhoven, S.; Van Eerd, M.C.J. Solidarity in water management. Ecol. Soc. 2016, 21, 35. [CrossRef] 
47. Keessen, A.M.; Hamer, J.M.; van Rijswick, H.F.M.W.; Wiering, M.A. The Concept of Resilience from a Normative Perspective: Examples from Dutch Adaptation Strategies. Ecol. Soc. 2013, 18, 45. [CrossRef]

48. Bijker, W.E. Do Not Despair: There Is Life after Constructivism. Sci. Technol. Hum. Values 2019, 18, 113-138. [CrossRef]

49. Driessen, P.P.J.; Van Rijswick, H.F.M.W. Normative aspects of climate adaptation policies. Clim. Law 2011, 2, 559-581. [CrossRef]

50. Haasnoot, M.; Middelkoop, H.; Offermans, A.; Van Beek, E.; Van Deursen, W.P.A. Exploring pathways for sustainable water management in river deltas in a changing environment. Clim. Change 2012, 115, 795-819. [CrossRef]

51. De La Vega-Leinert, A.C.; Stoll-Kleemann, S.; Wegener, E. Managed Realignment (MR) along the Eastern German Baltic Sea: A Catalyst for Conflict or for a Coastal Zone Management Consensus. J. Coast. Res. 2018, 34, 586-601. [CrossRef]

52. O'Brien, K. Global environmental change II: From adaptation to deliberate transformation. Prog. Hum. Geogr. 2012, 36, 667-676. [CrossRef]

53. Mehta, L. Water and human development. World Dev. 2014, 59, 59-69. [CrossRef]

54. Doorn, N. Distributing Risks: Allocation Principles for Distributing Reversible and Irreversible Losses. Ethics Policy Environ. 2018, 21, 96-109. [CrossRef]

55. Jepson, W.; Budds, J.; Eichelberger, L.; Harris, L.; Norman, E.; O’Reilly, K.; Pearson, A.; Shah, S.; Shinn, J.; Staddon, C.; et al. Advancing human capabilities for water security: A relational approach. Water Secur. 2017, 1, 46-52. [CrossRef]

56. Walker, G. Environmental Justice and Normative Thinking. Antipode 2009, 41, 203-205. [CrossRef]

57. Fünfgeld, H.; Schmid, B. Justice in climate change adaptation planning: Conceptual perspectives on emergent praxis. Geogr. Helv. 2020, 75, 437-449. [CrossRef]

58. Sen, A. The Idea of Justice; Penguin Books: London, UK, 2009.

59. Doorn, N. Water Ethics: An Introduction; Rowman \& Littlefield International: Lanham, MD, USA, 2019; ISBN 9781786609502.

60. Robeyns, I. Wellbeing, Freedom and Social Justice: The Capability Approach Re-Examined; Open Book Publishers: Cambridge, UK, 2017; ISBN 9781783744213.

61. Wolff, J.; De-Shalit, A. Disadvantage; Wolff, J., De-Shalit, A., Eds.; Oxford University Press: New York, NY, USA, 2007.

62. Robeyns, I. The capability approach in practice. J. Political Philos. 2006, 14, 351-376. [CrossRef]

63. Schlosberg, D.; Collins, L.B.; Niemeyer, S. Adaptation policy and community discourse: Risk, vulnerability, and just transformation. Environ. Polit. 2017, 26, 413-437. [CrossRef]

64. Sen, A. Dialogue capabilities, lists, and public reason: Continuing the conversation. Fem. Econ. 2004, 10, 77-80. [CrossRef]

65. Sen, A. Development as Freedom; Alfred, A., Ed.; Knopf: New York, NY, USA, 1999.

66. Nussbaum, M.C. Creating Capabilities: The Human Development Approach; Belknap Press of Harvard University Press: Cambridge, MA, USA, 2011.

67. Byskov, M.F. Democracy, Philosophy, and the Selection of Capabilities. J. Hum. Dev. Capab. 2017, 18, 1-16. [CrossRef]

68. Hickey, C.; Robeyns, I. Planetary justice: What can we learn from ethics and political philosophy? Earth Syst. Gov. 2020, 6, 100045. [CrossRef]

69. Melin, A. Should we Ascribe Capabilities to Species and Ecosystems? A Critical Analysis of Ecocentric Versions of the Capabilities Approach. J. Agric. Environ. Ethics 2021, 34, 26. [CrossRef]

70. Wesselink, A.; Buchanan, K.S.; Georgiadou, Y.; Turnhout, E. Technical knowledge, discursive spaces and politics at the sciencepolicy interface. Environ. Sci. Policy 2013, 30, 1-9. [CrossRef]

71. Bryman, A. Social Research Methods, 4th ed.; Oxford University Press: Oxford, UK, 2012.

72. Bijker, W.E. The Oosterschelde Storm Surge Barrier: A Test Case for Dutch Water Technology, Management, and Politics. Technol. Cult. 2002, 43, 569-584. [CrossRef]

73. Jasanoff, S.; Markle, G.E.; Petersen, J.C.; Pinch, T. Handbook of Science and Technology Studies; Jasanoff, S., Markle, G.E., Petersen, J.C., Pinch, T., Eds.; Sage Publications: Thousand Oaks, CA, USA, 1995; Volume 34, ISBN 0-7453-1686-7.

74. Ferguson, H.A.; Wolff, W.J. Haringvliet-Project: The Development of the Rhine-Meuse Estuary from Tidal Inlet to Stagnant Freshwater Lake. Water Sci. Technol. 1983, 16, 11-26. [CrossRef]

75. Dewey, J. The Public and Its Problems; Henby Holt and Company: New York, NY, USA, 1927.

76. Ysebaert, T.; van der Hoek, D.J.; Wortelboer, R.; Wijsman, J.W.M.; Tangelder, M.; Nolte, A. Management options for restoring estuarine dynamics and implications for ecosystems: A quantitative approach for the Southwest Delta in the Netherlands. Ocean Coast. Manag. 2016, 121, 33-48. [CrossRef]

77. Buitink, J.; Melsen, L.A.; Teuling, A.J. Seasonal discharge response to temperature-driven changes in evaporation and snow processes in the Rhine Basin. Earth Syst. Dyn. 2021, 12, 387-400. [CrossRef]

78. Ruessink, M. The Future of the Haringvliet Sluices Research to the Lifetime of the Haringvliet Sluices and an Evaluation of Conceptual Designs. Master's Thesis, Delft University of Technology, Delft, The Netherlands, 2019.

79. Dieperink, C. From open sewer to salmon run: Lessons from the Rhine water quality regime. Water Policy 1998, 1, 471-485. [CrossRef]

80. Van Slobbe, E.; Werners, S.E.; Riquelme-Solar, M.; Bölscher, T.; Van Vliet, M. The future of the Rhine: Stranded ships and no more salmon? Reg. Environ. Change 2016, 16, 31-41. [CrossRef]

81. Cioc, M. The Rhine: An Eco-Biography 1815-2000; Weyerhause; University of Washington Press: Seatlle, WA, USA; London, UK, 2002. 
82. Disco, C. Remaking "nature": The ecological turn in Dutch water management. Sci. Technol. Hum. Values 2002, 27, 206-235. [CrossRef]

83. Wiering, M.A.; Arts, B.J.M. Discursive Shifts in Dutch River Management: 'Deep' Institutional Change or Adaptation Strategy? Hydrobiologia 2006, 565, 327-338. [CrossRef]

84. Rijksoverheid Besluit Beheer Haringvlietsluizen 2000. Available online: https://wetten.overheid.nl/BWBR0011395/2009-12-22 (accessed on 22 November 2021).

85. Van Eerd, M.C.J.; Wiering, M.A.; Dieperink, C. Solidarity in transboundary flood risk management: A view from the Dutch North Rhine-Westphalian catchment area. Clim. Policy 2017, 17, 261-279. [CrossRef]

86. Warner, J.F. Of River Linkage and Issue Linkage: Transboundary Conflict and Cooperation on the River Meuse. Globalizations 2016, 13, 741-766. [CrossRef]

87. Van Meerkerk, I.; Van Buuren, A.; Edelenbos, J. Water Managers' Boundary Judgments and Adaptive Water Governance. An Analysis of the Dutch Haringvliet Sluices Case. Water Resour. Manag. 2013, 27, 2179-2194. [CrossRef]

88. Rottler, E.; Bronstert, A.; Bürger, G.; Rakovec, O. Projected changes in Rhine River flood seasonality under global warming Hydrol. Earth Syst. Sci. Discuss. 2021, 25, 2353-2371. [CrossRef]

89. Klijn, F.; Hegnauer, M.; Beersma, J.; Sperna Welland, F. Wat Betekenen de Nieuwe Klimaatscenario's Voor de Rivierafvoeren van Rijn en Maas? Deltares: Delft, The Netherlands, 2015.

90. KNMI Koninklijk Nederlands Metereologisch Instituut: Klimaat. Available online: https://www.knmi.nl/klimaat (accessed on 8 November 2021).

91. Haasnoot, M.; Kwadijk, J.; Van Alphen, J.; Le Bars, D.; Van Den Hurk, B.; Diermanse, F.; Van Der Spek, A.; Oude Essink, G.; Delsman, J.; Mens, M. Adaptation to uncertain sea-level rise; how uncertainty in Antarctic mass-loss impacts the coastal adaptation strategy of the Netherlands. Environ. Res. Lett. 2020, 15, 034007. [CrossRef]

92. Smits, A.J.M.; Nienhuis, P.H.; Saeijs, H.L.F. Changing estuaries, changing views. Hydrobiologia 2006, 565, 339-355. [CrossRef]

93. Haasnoot, M.; Diermanse, F.; Kwadijk, J.; De Winter, R.; Winter, G. Strategieën voor Adaptatie aan Hoge en Versnelde Zeespiegelstijging. Een Verkenning; Deltares: Delft, The Netherlands, 2019.

94. Bohman, J.; Rehg, W. Deliberative Democracy: Essays on Reason and Politics; Bohman, J., Regh, W., Eds.; The MIT Press: Cambridge, UK, 1997.

95. Nussbaum, M. The Monarchy of Fear, 1st ed.; Oxford University Press: Oxford, UK, 2018.

96. Meyer, L.H.; Sanklecha, P. How legitimate expectations matter in climate justice. Political Philos. Econ. 2014, 13, 369-393. [CrossRef]

97. Green, F.; Gambhir, A. Transitional assistance policies for just, equitable and smooth low-carbon transitions: Who, what and how? Clim. Policy 2020, 20, 902-921. [CrossRef]

98. Taebi, B.; Kermisch, C. Governing climate risks in the face of normative uncertainties. Wiley Interdiscip. Rev. Clim. Change 2020, 11, e666. [CrossRef]

99. Goddard, J.J.; Kallis, G.; Norgaard, R.B. Keeping multiple antennae up: Coevolutionary foundations for methodological pluralism. Ecol. Econ. 2019, 165, 106420. [CrossRef]

100. Stirling, A. "Opening up" and "closing down": Power, participation, and pluralism in the social appraisal of technology. Sci. Technol. Hum. Values 2008, 33, 262-294. [CrossRef]

101. Warner, J.F.; Van Buuren, A. Multi-stakeholder learning and fighting on the river scheldt. Int. Negot. 2009, 14, 419-440. [CrossRef]

102. Roth, D.; Vink, M.; Warner, J.; Winnubst, M. Watered-down politics? Inclusive water governance in the Netherlands. Ocean Coast. Manag. 2017, 150, 51-61. [CrossRef]

103. Day, J.W.; Colten, C.; Kemp, G.P. Mississippi Delta Restoration and Protection: Shifting Baselines, Diminishing Resilience, and Growing Nonsustainability; Elsevier: Amsterdam, The Netherlands, 2019; ISBN 9780128140048.

104. Colten, C.E. Adaptive Transitions: The Long-Term Perspective on Humans in Changing Coastal Settings. Geogr. Rev. 2019, 109, 416-435. [CrossRef] 